\title{
41. 放射線治療における照射位置の再現性(骨盤)
}

Patient set-up reproducibility in radiation therapy

日本赤十字社医療センター O田中 啓一

日本医科大学病院川原崎 昇

社会保険船橋中央病院島田和幸

社会保険中央総合病院坂井英章・本宿 喜一

国立がんセンター 黑沢秀雄・林 久貴・勝田昭一
癌研究会附属病院 桑原 秋夫・木村 雅春 東京医科大学病院 横山公一・久保 浩二 日本大学医学部附属板橋病院遠藤 裕二 東京医科菓科大学病院久馬幸重 新橋内科クリニック 和久井聖

【目的】患者セッティングの方法は施設により様々である。患者体位の再現性を調べるために、リ二 アックグラムの照射野を基準として、皮痛マーク、骨格基準線、骨盤基準線、それらに対する誤差を 施設別に調心、検討をする。

【方法】一人の患者について最大 5 回を目標として、リニアックグラムを撮影して次に述べる(1)（5) までの5項目について測定在行う。

(1)皮膚マークとの誤差：体表面に描かれた皮疸マークの中心と、その中心から伸びた延長線上最端の 上卡、左右の 5 カ所に七ューズを張り、撮影をする。リニアックグラムのX線照射野の中心点を作図 する、次に各のとューズの中心点の交点を作図する、以上によりX線照射野中心を原点としたXY座 標と、極座標として、体表面七ューズによる中心点との誤差を $X_{j}, Y_{j}, \theta_{x}, \theta_{y}$ ，を測定する。 (2)骨格基準線との誤差：リニアックグラムに写る左右の大腿骨骨頭を結ぶ直線を作图する、これに垂 直一等分線を加え交点を求める。以上によりX線照射野中心を原点としたXY座標、極座標として測 定をした值を $\mathrm{X}_{0 \mathrm{j}}, \mathrm{Y}_{01}, \theta_{x_{\mathrm{j}}}, \theta_{y \mathrm{j}}$, とする。このとき、1 回目の測定值を 2 回目以降の測定值から 差し引いたものを使用したため1回目の值は、ゼロとする。

(3)骨盤基準線との誤差 : リニアックグラムに写る小骨盤の左の部分とX線照射野の左端までの距離を $\mathrm{X}_{1 \mathrm{j}}$, 同じく右の部分とX線照射野の右端までの距離を $\mathrm{X}_{2 \mathrm{j}}$, とする。

リニアックグラムに写る第五腰椎上縁とXX線照射野の上端までの距離を $Y_{1 j}$, 同じく恥骨上縁と $X$ 線 照射野の下端までの距離を $\mathrm{Y}_{2 \mathrm{j}}$, とする。このとき、1回目の測定值を 2 回目以降の測定值から差し 引いたものを使用したため 1 回目の値は、ゼロとする。

(4)皮膚マークから見た場合の骨格基準線との䛊差: 一回毎の X, Y, $\theta_{x}, \theta_{y}$ ，の差を求める。

(5)皮膚マークから見た場合の骨盤基準線との䛣差:一回每のX，Y，の差を求める。

以上の誤差をもとに私設ごとの相違や経時的変化を調べる。

測定値の共通性を得るため、アイソセンターを基準とし、搪大率で除したものを使用した。

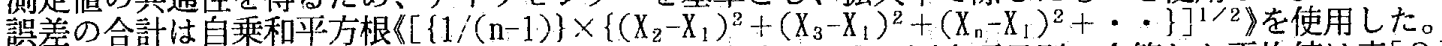

【結果】参加施設と測定人数は表[1]であった、方法(1)〜(3)の測定項目別に合算した平均值は表 [2]

であった。

方法(4) 5 回の 測定ができた 4

施設 5 人分を 1

回每の変化量之

LてX Y 座標、

極座標による変

の範囲を図 $[1]$

で表した。

方法(5)は 5 回の

\begin{tabular}{|c|c|c|c|c|}
\hline 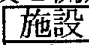 & 人数 & 5 可 & $4[0$ & 3回 \\
\hline A & & 2 & - & \\
\hline B & 3 & & 1 & 1 \\
\hline$C$ & 2 & & 1 & \\
\hline D & 2 & 1 & 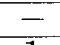 & \\
\hline $\mathrm{E}$ & 2 & - & 1 & \\
\hline$F$ & & $=$ & $\overline{-}$ & \\
\hline $\begin{array}{c}G \\
\text { 合計 }\end{array}$ & 13 & - & - & 5 \\
\hline
\end{tabular}

測定ができた 4 施設 5 人分の䛊差を加算したグラフ

[1]の様であった。

【考察】測定患者

の厚さは $16 \sim 20 \mathrm{~cm}$ 測定期間は 5 週間 でその間に変化は

見られなかった。

【結論】合計した 結果より、

横方向 $2.1 \mathrm{~mm} \pm 0.2$ 縦方向 2.4 min士 0.7 のマージンが得ら れた。今回の測定 では、標淮的な人 であったが、縦方 向について誤差が 増大していた。

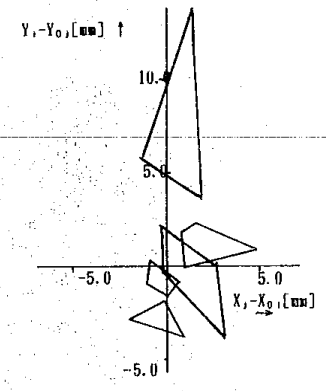

$[$ [Q] $[1]$

\begin{tabular}{|c|c|c|c|c|c|}
\hline \multicolumn{2}{|l|}{ 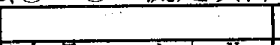 } & $\exists 1$ & & 8 & \\
\hline \multirow{3}{*}{ 考眉マーク } & $\Lambda_{-}$ & \pm 1.2 & $2 \mathrm{~mm}$ & $5.6 \mathrm{~mm}$ & \\
\hline & & $8+0.8$ & 8 mm & $2.6 \mathrm{~mm}$ & \\
\hline & & $2+02$ & 花渡 & 1.8 凅 & \\
\hline \multirow{4}{*}{ 骨格基準線 } & & & $\mathrm{mm}$ & & \\
\hline & $Y_{01}$ & 3. & $\mathrm{Imm}$ & 7.5 & \\
\hline & & & 度 & 2.5 度 & \\
\hline & $\theta_{f}$ & $4 \pm 0$ & 度 & 3.8 度 & \\
\hline \multirow{3}{*}{ 無盤基潐線 } & $x_{!}$ & 1. & m & & \\
\hline & & 2 & min & $\frac{9.1 \mathrm{~mm}}{0}$ & \\
\hline & & $3.2 \pm$ & min & $7.9 \mathrm{~mm}$ & \\
\hline
\end{tabular}
表[2]

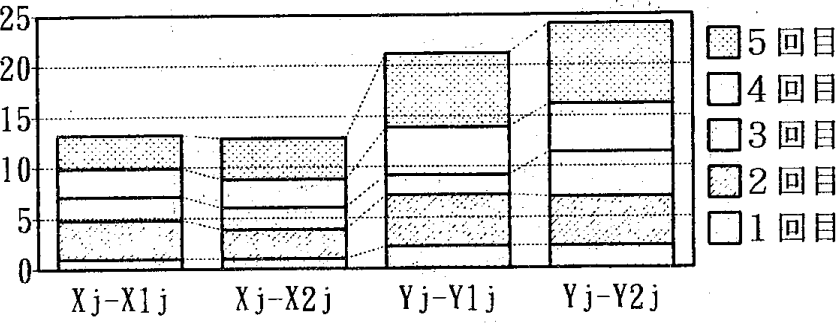

グラフ $[1]$ 